\title{
A FORMAÇÃO INTERDISCIPLINAR DE PROFESSORES/AS DE ARTES NA UFSB: CURRÍCULO E POLÍTICA DO CONHECIMENTO
}

\author{
AUTOR: MIQUEIAS SILVA QUEIROZ \\ CO-AUTOR/ORIENTADOR: GESSE ALMEIDA ARAUJO
}

\begin{abstract}
Resumo: O presente trabalho de pesquisa, parte do projeto intitulado "Análise de contextos formativos de professores/as de Artes da Educação Básica no município de Teixeira de Freitas - Bahia", no qual analisa-se a conjuntura da formação de professores/as de Artes atuantes nas redes municipal e estadual da educação básica pública em Teixeira de Freitas/BA. Entre os principais desafios conceituais na formação de professores e professoras em Artes pode-se destacar as diferentes concepções teóricas do papel da arte na educação, a relação entre a teoria e a prática, a relação processo/produto, entre outras. Na etapa a qual atem-se este trabalho, desenvolveu-se o plano de trabalho intitulado "A formação interdisciplinar de professores/as de Artes na UFSB: currículo e política do conhecimento", partindo-se de uma análise qualitativa do Projeto Pedagógico da Licenciatura Interdisciplinar em Artes e suas Tecnologias do campus Paulo Freire. Desse modo, chegou-se a uma análise acerca das percepções dos/das estudantes de Artes sobre o referido documento que resguarda o curso, lido a partir do conceito de interdisciplinaridade como política do conhecimento. Através de uma pesquisa teórica sobre os temas em arte/educação e fundamentos das teorias dos currículos, além da coleta de dados a partir da aplicação de formulários, pode-se analisar a visão dos/as estudantes da LI Artes a respeito da formação de professores e professoras no âmbito da UFSB. A visada dos/das discentes permitiu observar as possíveis lacunas, os excessos, as metodologias e as práticas dentro da formação de professores/professoras de Artes. Diante disso, pretende-se compor as bases para a reflexão de possíveis avanços e correção de incongruências.
\end{abstract}

Palavras-Chave: Artes. Ensino de Artes. Educação Artística. Currículo. Formação docente. 